\title{
一般化安定化補償器による反力推定を利用した ロボットハンドの把持機構の制御*
}

\author{
谷 正 史 ${ }^{* 1}$, 鈴木 亮 *2 $^{* 2}$ 鳥田 武司*3 \\ 藤木 信 彰*2, 小林 伸 明*4

\section{Mechanism of Robot Hand Using on Control for Grasping by All Stabilizing Controller} \\ Masashi TANI*5, Ryoichi SUZUKI, Takeshi TORITA, \\ Nobuaki FUJIKI and Nobuaki KOBAYASHI \\ ${ }^{* 5}$ Engineering Education Center, Kanazawa Institute of Technology, \\ 7-1 Ohgigaoka, Nonoichi, Ishikawa-gun, Ishikawa, 921-8501 Japan

\begin{abstract}
In this paper, we propose a control system for a prototype robotic hand that can hold an object with suitable grasping force without using a force sensor. This control system is composed of two 1-DOF robot hands and a CCD camera. The control system recognizes the object with the CCD camera, and the database retrieves the suitable grasping force for holding each object. We propose the control method of a reduced order observer-based stabilizing controller by using limiting properties of LQR for this control system. The proposed reduced order observer-based stabilizing controller has disturbance estimation property and disturbance decoupling property which is the same as the internal model control design structure. We apply the proposed method to the robot hand, and confirm effectiveness of the method by comparative experiments.
\end{abstract}

Key Words: Linear Optimal Quadratic Regulators (LQR), All Stabilizing Controller, Internal Model Control (IMC), Robot Hand, Reduced Order Observer

\section{1. はじめに}

人が物を垷んで持ち運びするときは, 物体を握り潰 さずかつ落とさないように適度な力で把持している. 例えば，紙コップやトマト等軟らかい物を掴む場合が そうである. 人が物体を把持する際は，その形状，大 きさ，色等の視覚情報から経験的に把持力を予め決め て把持する行動と，触れたときの質感から徐々に力を 加減して把持する行動がある.これと同じことをロボ ットハンドで行う場合，圧力センサやカセンサを用い て掴む力を検出し把持する方法があるが，圧力センサ 等を用いた装置で任意の物体を把持する際の欠点は, (a)掴む物体の形状や大きさによりセンサの取り付け 位置や個数の調整が必要となる, (b)温度・水分等の使 用環境がセンサにより制限されてしまう，(c)検出する 力の最大許容值が大きいセンサで小さい值を計測す る場合は精度が低下寸る, また逆に最大許容值が小さ いセンサで質量の大きいものを把持できない等，セン サの仕椂や特性による制約条件が加わる.

このため本論文では, 圧力センサ等を用いることな

\footnotetext{
* 原稿受付 2006 年 4 月 21 日

*1 正員, 全沢工業大学工学設計教育センター(画 921-8501 石 川県石川郡野々市町扇が丘 7-1).

*2 正員, 金沢工業大学工学部.

*3 金沢工業大学大学院工学研究科.

*4 金沢工業大学工学部.

E-mail : tani@neptune.kanazawa-it.ac.jp
}

く人が行う把持行為をロボットハンドで実現するシ ステムとして, 視覚情報から物体を特定しその物体に 見合った把持力を設定して把持する制御系を提案し， 実験により検証を行う．圧力センサ等を用いずにこれ を実現するための制御は，ロボットハンドが把持対象 物に接触した際の反力を外乱として捉え, この未知外 乱を推定しその值を基に把持制御を行うもので，制御 系の構成は低次元オブザーバを用いた一般化安定化 補償器(10)を利用したものである。

本論文の構成は, 2 章で把持装置全体の構成を示し， 3 章で最適レギュレータと状態推定の極限的性質, 一 般化安定化補償器および内部モデル制御(2)の特性につ いて概説する. 4 章では，提案する制御系の基本であ る低次元オブザーバに基く一般化安定化補償器の構 成法と特性を示す. 5 章では， 4 章で提案した制御系 を 2 章の把持機構に適合するよう発展させた新しい制 御系を提案し， 6 章で把持制御のための具体的な制御 系設計と実験結果について述べその有効性を示寸.

\section{2. 把持システムの權成}

人が物体を認識し，その物体に見合った適切な力で 把持する動作を再現するシステムとして，図1のよう 
なシステムを提案する. この提案システムの把持動作 手順を述べる.

まず人が視覚から物を認識するための行為として, (1)パーソナルコンピュータ(以下，PC)は， CCD カメ ラから得た形状, 色等の情報から物体を特定する. 次 にその物体に見合った適切な掴む力を設定する行為 として，(2)PC には物体に応じた把持力が予めデータ ベース化されており，その把持力(以下, 設定把持力 $\alpha$ ) を読み出す．次に対象物に見合った力で把持する動作 を行うために，(3)PC は後述する制御則に従って物体

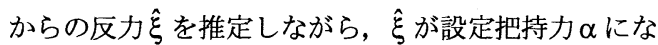
るまでアームを駆動する. (4)反力 $\hat{\xi} か ゙$ 設定把持力 $\alpha$ と 等しくなると, 制御系の構成を切り換えて把持を行う. これが提案システムの一連の動作である.

なお, 把持対象物として硬さの軟・硬, 質量の大・小, 形状の違いから，今回はトマト，紙コップ，金属製立 方体を評価対象物とした。データベースに登録した 各々の設定把持力 $\alpha$ を表 1 に示す. 本来, データベー スには多くの物体を用意すべきであるが，ここでは物 体認識を主テーマとしていないため, HALCON(3)によ り比較的識別容易な 3 種類の対象物とした.

把持に用いるロボットハンドには，それ自体が動き 回るためのタイヤが取り付けられており，CCD カメ ラからの画像情報を基に自立移動が可能となる構造 である，その機能は， 1 自由度の 2 本のアームを各々 独立したモータで駆動し，把持対象物まで画像情報を 基に自立移動して，その物体に見合った力で把持する ものである. しかし, 本論文の主テーマは把持制御で あるため，自立移動についてはここではふれない。

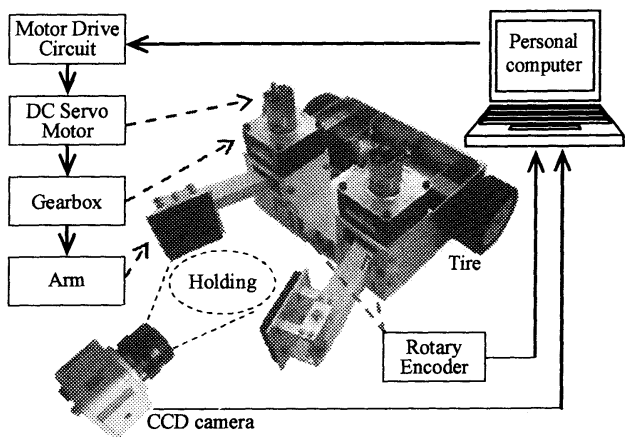

Fig.1 Robot hand and control system structure

Table.1 Desired grasping force $\alpha$

\begin{tabular}{|c||c|c|c|}
\hline Object & Metallic cube & Tomato & Paper cup \\
\hline$\alpha[\mathrm{Nm}]$ & 3.0 & 1.0 & 0.4 \\
\hline
\end{tabular}

\section{3. 一般化安定化補賲器と内部モデル制御}

2 章で述べた把持システムの実現のための把持制御 を考える前に, 一般化安定化補償器と内部モデル制御 の概要について述べておく.

3・1 一般化安定化補頭器 次のような外乱が 印加される線形システム

$$
\dot{x}=A x+B u+D \xi, \quad y=C x
$$

を考える.ここで, $x \in R^{n}$ は状態, $u \in R^{m}$ は入力, $y \in R^{p}$ は出力であり， $\xi \in R^{r}$ は外乱とする. このと き, システム $(A, B, C)$ の伝達関数 $\Sigma(s)$ に対し, 全ての 安定化補償器 $K(s)$ は,

$$
K(s)=(Y-M Q)(X-N Q)^{-1}, \operatorname{det}(X-N Q) \neq 0
$$

で与えられる.ただし， $Q \in R H_{\infty}, \Sigma(s)=N M^{-1}$ で $X$ ， $Y$ はべズー方程式の解である.これを状態フィードバ ックとオブザーバで実現する. つまり, 各々のゲイン を $F, L$ として $A+B F, A+L C$ を安定とする安定 化補償器の一般形 $K(s)$ は,

$$
\begin{aligned}
& K(s)=\operatorname{LFT}\{M(s), Q(s)\}, \quad Q(s) \in R H_{\infty} \\
& M(s)=\left(\begin{array}{c:cc}
A+B F+L C & -L & B \\
\hdashline F & 0 & I \\
C & -I & 0
\end{array}\right)
\end{aligned}
$$

で与えられる(1).ここで, $M(s)$ はドイルの記法に従っ た伝達関数を表す.

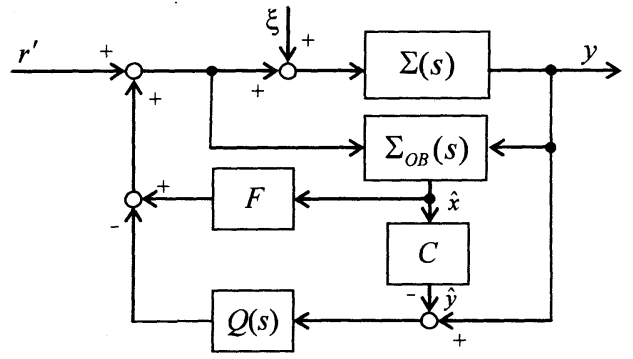

Fig.2 Observer based all stabilizing controller

ここで用いるロボットハンドは, 入力端に外乱が加 わるので, 式(1)は

$$
\dot{x}=A x+B u+B \xi, \quad y=C x
$$

と表現できる.ここで，外部入力を $r^{\prime}(t)$ ，オブザーバ の変数を $\hat{x}$, 状態推定の誤差 $e=\hat{x}-x$, および $y-\hat{y}=-C e$ を定義すると, 安定化補償器の一般形を 用いた図 2 に示す制御系の拡大系は, 式(5)のように整 理できる.ここで, $x_{e}=\left(\begin{array}{lll}x & e & \eta\end{array}\right)^{T}$ であり, $\left(A_{Q}, B_{Q}, C_{Q}, D_{Q}\right)$ は $Q(s)$ の最小実現である. 


$$
\begin{aligned}
\dot{x}_{e}= & \left(\begin{array}{ccc}
A+B F & B\left(F+D_{Q} C\right) & -B C_{Q} \\
0 & A+L C & 0 \\
0 & -B_{Q} C & A_{Q}
\end{array}\right) x_{e} \\
& +\left(\begin{array}{c}
B \\
0 \\
0
\end{array}\right) r^{\prime}+\left(\begin{array}{c}
B \\
-B \\
0
\end{array}\right) \xi \\
y & =\left(\begin{array}{lll}
C & 0 & 0
\end{array}\right) x_{e}
\end{aligned}
$$

図 2 に示寸制御系の構成法に関して, 状態空間から のゲイン設定や補償器設計の自由度を活用する方法 についての研究はあまりなされていない,一方, 内部 モデル制御は，制御対象のモデルを内蔵するため制御 対象が安定か状態が既知である必要があり，かつコン トローラの次数が増大する点が指摘されている. そこ で, ここでの一般化安定化補償器の構成では, 次節の 性質を使って 4 章で示す低次元オブザーバと最適レギ ユレータの極限的性質を利用して, ゲイン $F, L$ の選 定を行い, $Q(s)$ の構成により外乱推定と外乱除去が可 能となることを示し, この制御系の構成を発展させ把 持を行うのに適した制御系を新しく提案する.

上述の点を明らかにする隻備として, 最適レギュレ 一タとオブザーバの極限的性質および内部モデル制 御の特性について以下に述べる.

3 - 2 取道レギュレータと状䉥推定の桓限特性と 内部モデル制御 式(1)の外乱のない次の線形シ ステムを考える.

$$
\dot{x}=A x+B u, \quad y=C x
$$

ここで, システム $(A, B, C)$ は可制御, 可観測で可逆と する. このシステムに対し, 評価関数

$$
J=\int_{0}^{\infty}\left(y^{T} \widetilde{Q} y+u^{T} R u\right) d t, \widetilde{Q}>0, R>0
$$

を最小とする制御入力 $u$ は, 重み行列を $R=I$, $\widetilde{Q} \rightarrow\left(1 / \varepsilon^{2}\right) \cdot I$ とし $\varepsilon \rightarrow 0$ とすれば,

$$
\begin{aligned}
& u=F_{\varepsilon} x=-B^{T} P_{\varepsilon} x \\
& A^{T} P_{\varepsilon}+P_{\varepsilon} A-P_{\varepsilon} B B^{T} P_{\varepsilon}+\varepsilon^{-2} C^{T} C=0
\end{aligned}
$$

\section{と導ける.}

ここで, $\varepsilon \rightarrow 0$ とした $F_{\varepsilon}$ を極限フィードバックゲイ ンと呼び, これを施した閉ループ系に対して, 次の外 乱除去特性が導かれる.

[補題 1] ${ }^{(4),(5)}$ 外乱が加わるシステム $(A, B, C, D)$ に おいて極限フィードバックを施した閉ループ系の外 乱 $\xi$ から出力 $y$ までの伝達関数は, システム $(A, B, C)$ の不変零点から

$$
\operatorname{rank}\left(\begin{array}{ccc}
-s I+A & B & D \\
C & 0 & 0
\end{array}\right)<n+m
$$

を満たす $s$ を除いたものが安定であるとき

$$
\lim _{\varepsilon \rightarrow 0} C\left(s I-A-B F_{\mathrm{\varepsilon}}\right)^{-1} D=0
$$

となり極限において外乱除去を達成する.

さらにLQ制御の双対としてオブザーバを考えると き, オブザーバの誤差方程式に関して次の補題を得る. [補題 2] ${ }^{(6),(7)}$ 最小位相系 $(A, B, C)$ に対してオブザ 一バを次のように構成する.

$$
\begin{aligned}
& \dot{\hat{x}}=\left(A+L_{\rho} C\right) \hat{x}-L_{\rho} y+B u \\
& L_{\mathrm{\rho}}=-M_{\varepsilon} C^{T} \\
& A^{T} M_{\mathrm{\rho}}+M_{\mathrm{\rho}} A-M_{\rho} C C^{T} M_{\mathrm{\rho}}+B^{T} B \rho^{-2}=0
\end{aligned}
$$

このとき, $\rho \rightarrow 0$ の極限において推定誤差は, 未知外 乱乡のもと $e \rightarrow 0$ を達成する. すなわち,

$$
\lim _{\rho \rightarrow 0}\left(s I-A-L_{\rho} C\right)^{-1} B=0
$$

が成り立つ.

次に，内部モデル制御と極限フィードバックを併用 したときの外乱除去特性について述べておく. 式(4) のシステムに対して,

$$
u=F_{\varepsilon} x+v
$$

という, 最適レギュレータのフィードバックを施し, これを,

$$
\Sigma_{f}: \dot{x}=\left(A+B F_{\varepsilon}\right) x+B v+B \xi, \quad y=C x
$$

とする. この $\Sigma_{f}$ のモデル $\bar{\Sigma}_{f}$ を

$$
\bar{\Sigma}_{f}: \dot{x}=\left(A+B F_{\mathrm{\varepsilon}}\right) x+B v, \quad y=C x
$$

とし， $\bar{\Sigma}_{f}$ の近似逆システムの伝達関数を $\bar{\Sigma}_{f t}^{-1}(s)$ とす ると

$$
\bar{\Sigma}_{f}^{-1}(s) \cdot \bar{\Sigma}_{f}(s)=\operatorname{diag}\left((\tau s+1)^{-d_{1}}, \cdots,(\tau s+1)^{-d_{m}}\right)
$$

と定義される. ただし， $\tau<1 ， d_{i}$ は $\bar{\Sigma}_{f \tau}^{-1}(s)$ をプロパ 一とする最小積分指数である. このとき, 図 3 に示す 構成が内部モデル制御の一つであり次の特性を持つ.

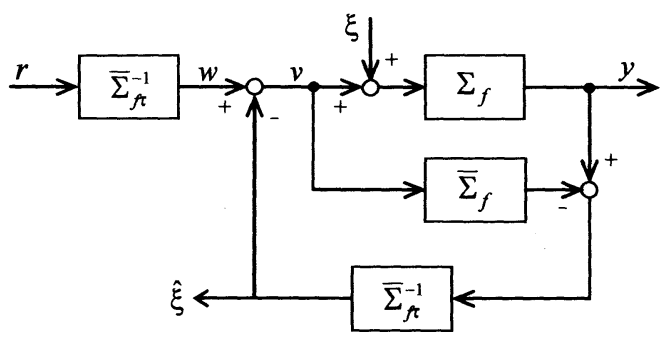

Fig.3 Internal Model Control design structure 
[補題 3] ${ }^{(8)}$ フィードバック $u=F_{\varepsilon} x$ と内部モデル制 御を併用することで, 内部モデル制御が持つ外乱除去 特性と, 最適レギュレータの極限的性質が持つ外乱除 去特性の二つの効果により, $\varepsilon, \tau \rightarrow 0$ の極限において 出力 $y$ から外乱 $\xi$ まで伝達関数は $H_{y \xi}(s) \rightarrow 0$ を達

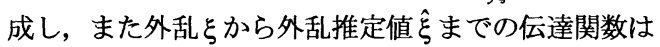

$$
H_{\hat{\xi} \xi}(s)=I
$$

となる.

\section{4. 低次元オブザーパによる一役化安定化補传器 の特性と把持制御システム}

4.1 低次元オブザーバの導入一般化安定化補 償器に低次元オブザーバを用いて構成する為, オブザ 一バの低次元化について述べる。ここで用いるロボッ トハンドでは $C B=0$ を満足するため, 適当な変換行 列を用いて

$$
\begin{aligned}
& \left(\begin{array}{l}
\dot{x}_{1} \\
\dot{x}_{2}
\end{array}\right)=\left(\begin{array}{ll}
A_{11} & A_{12} \\
A_{21} & A_{22}
\end{array}\right)\left(\begin{array}{l}
x_{1} \\
x_{2}
\end{array}\right)+\left(\begin{array}{c}
0 \\
B_{2}
\end{array}\right) u+\left(\begin{array}{c}
0 \\
B_{2}
\end{array}\right) \xi \\
& y=\left(\begin{array}{ll}
I_{p} & 0
\end{array}\right)\left(\begin{array}{l}
x_{1} \\
x_{2}
\end{array}\right)
\end{aligned}
$$

と表現できる. 式(21)から y の微分值は,

$$
\dot{y}=A_{11} y+A_{12} x_{2}
$$

である.そこで,

$$
\left\{\begin{array}{l}
\dot{x}_{2}=A_{22} x_{2}+A_{21} y+B_{2} \xi+B_{2} u \\
\varphi=\dot{y}-A_{11} y=A_{12} x_{2}
\end{array}\right.
$$

に対して, $(n-p)$ 次元オブザーバを次のように構 成する.

$$
\dot{\hat{x}}_{2}=\left(A_{22}+\bar{L}_{\rho} A_{12}\right) \hat{x}_{2}-\bar{L}_{\rho}\left(\dot{y}-A_{11} y\right)+A_{21} y+B_{2} u(24)
$$

ただし， $\bar{L}_{\rho}$ は次のように求められる.

$$
\begin{aligned}
& \bar{L}_{\mathrm{\rho}}=-\bar{M}_{\mathrm{\rho}} A_{12}^{T} \\
& A_{22} \bar{M}_{\mathrm{\rho}}+\bar{M}_{\mathrm{\rho}} A_{22}^{T}-\bar{M}_{\mathrm{\rho}} A_{12}^{T} A_{12} \bar{M}_{\mathrm{\rho}}+B_{2} B_{2}^{T} \mathrm{\rho}^{-2}=0 \\
こ & \text { で, } e_{2}=\hat{x}_{2}-x_{2} \text { とおくと誤差方程式は, } \\
& \dot{e}_{2}=\left(A_{22}+\bar{L}_{\mathrm{\rho}} A_{12}\right) e_{2}-B_{2} \xi
\end{aligned}
$$

となる.

以上から $(n-p)$ 次元オブザーバを用いた推定 誤差は次のようになる.

[補題 4] システム $(A, B, C)$ は最小位相系とする. このとき $(n-p)$ 次元オブザーバが構成でき, オブ ザーバの状態推定誤差 $e_{2}$ は $\rho \rightarrow 0$ の極限操作で式 (28)が成立する.

$$
\lim _{\rho \rightarrow 0}\left(s I-A_{22}-\bar{L}_{\rho} A_{12}\right)^{-1} B_{2} \rightarrow 0 \quad\left(\lim _{\rho \rightarrow 0} e_{2} \rightarrow 0\right)
$$

証明 : システム $(A, B, C)$ が最小位相系なら, サ ブシステム $\left(A_{22}, B_{2}, A_{12}\right)$ も最小位相系となる.した がって, サブシステムに補題 2 を適用すると式 (28)が成立する.

実際のオブザーバとしては，式(24)にyの微分 值を含むので, これを避けるため変数変換して

$$
\begin{aligned}
\hat{x}_{2}= & z-\bar{L}_{\rho} y \\
\dot{z}= & \left(A_{22}+\bar{L}_{\rho} A_{12}\right) z-\left(A_{22}+\bar{L}_{\rho} A_{12}\right) \bar{L}_{\rho} y \\
& +\bar{L}_{\rho} A_{11} y+A_{21} y+B_{2} u
\end{aligned}
$$

と，低次元オブザーバを構成すれば良い。なお， この場合オブザーバの性能はそのまま保存される.

ここで，状態推定と同時に内部モデル制御のよ うに外乱を推定するために，外乱 近似逆システムを構成する必要がある.このため, 式(27)，（30)に着目すると，次のようなシステム

$$
\left\{\begin{array}{l}
\dot{e}_{2}=\left(A_{22}+\bar{L}_{\rho} A_{12}\right) e_{2}-B_{2} \xi \\
\mu=-A_{12} e_{2}
\end{array}\right.
$$

とみなして, 安定な近似逆システムを構成できる。

$$
\operatorname{rank}\left(\begin{array}{cc}
-\lambda I+A_{22}+\bar{L}_{\rho} A_{12} & B_{2} \\
A_{12} & 0
\end{array}\right)<n+m-p
$$

を満たす $\lambda$ は, $(A, B, C)$ の零点に一致し, $(A, B, C)$ が左可逆で最小位相系とすると，式(31)のシステ ムも同様となる。よって，末知外乱 $\xi$ は,

$$
\xi=\left\{A_{12}\left(s I-A_{\bar{L}_{\mathrm{p}}}\right)^{-1} B_{2}\right\}^{-1}\left\{\left(s I-A_{11}\right) y-A_{12} \hat{x}_{2}\right\}
$$

となる.ここで, $A_{\bar{L}_{\mathrm{p}}}=A_{22}+\bar{L}_{\mathrm{\rho}} A_{12}$ とおいた

これより, 外乱 $\xi$ 推定值である $\hat{\xi}$ は,

$$
\begin{aligned}
\hat{\xi}= & \operatorname{diag}\left((\tau s+1)^{-d_{1}}, \cdots,(\tau s+1)^{-d_{m}}\right) \\
& \cdot\left\{A_{12}\left(s I-A_{\bar{L}_{p}}\right)^{-1} B_{2}\right\}^{-1}\left\{\left(s I-A_{11}\right) y-A_{12} \hat{x}_{2}\right\}
\end{aligned}
$$

で構成可能となる．実際設計するには利用できる 情報は $y$ と $\hat{x}_{2}$ であるから

$$
\begin{gathered}
\hat{\xi}(s)=\bar{Q}(s) \bar{\mu}(s) \\
\bar{Q}(s)=\operatorname{diag}\left((\tau s+1)^{-d_{1}+1}, \cdots,(\tau s+1)^{-d_{m}+1}\right) \\
\cdot\left\{A_{12}\left(s I-A_{\bar{L}_{\mathrm{p}}}\right)^{-1} B_{2}\right\}^{-1}
\end{gathered}
$$

$$
\begin{gathered}
\bar{\mu}(s)=\operatorname{diag}\left((\tau s+1)^{-1}, \cdots,(\tau s+1)^{-1}\right) \\
\cdot\left\{\left(s I-A_{11}\right) y-A_{12} \hat{x}_{2}\right\}=\bar{W}(s)\left(\begin{array}{c}
y \\
\hat{x}_{2}
\end{array}\right)
\end{gathered}
$$

で構成すれば実現可能である.

[注意 1]式(35)の近似逆系の次数は, 同一次元 オブザーバを用いた場合の逆系と同じである。よ 
って, コントローラ全体の次数は, 低次元オブザ ーバ分の次数が低下することになる.

$4 \cdot 2$ 低次元オブザーパによる一般化安定化㭪侻器 の特性 外乱推定と外乱除去特性を持つ低次元オブ ザーバを用いた一般化安定化補償器の構成として, 図 4 に示す構成を示しておく.ここで, $\bar{\Sigma}_{o b}$ は式(29), (30) の低次元オブザーバであり，コントローラと低次 元オブザーバのゲインを $F=F_{\varepsilon}, \bar{L}=\bar{L}_{\mathrm{\rho}}, G(s)$ を

$$
G(s)=\left\{C\left(-A-B F_{\varepsilon}\right)^{-1} B\right\}^{-1}
$$

と選定し， $\bar{Q}(s), \bar{W}(s)$ は式(36), (37)とする.

フィードバック制御則 $F_{\varepsilon} x$ は,

$$
F_{\varepsilon} x=F_{\varepsilon 1} x_{1}+F_{\varepsilon 2} \hat{x}_{2}=F_{\varepsilon 1} x_{1}+F_{\varepsilon 2} x_{2}+F_{\varepsilon 2} e_{2}
$$

と書けるから, 誤差方程式の近似逆システムの実 現を $\left(\bar{A}_{Q}, \bar{B}_{Q}, \bar{C}_{Q}, \bar{D}_{Q}\right)$ すると，拡大系は，

$$
\begin{array}{r}
\dot{x}_{e 2}=\left(\begin{array}{ccc}
A_{F_{\varepsilon}} & B\left(F_{\varepsilon 2}+\bar{D}_{Q} A_{12}\right) & -B \bar{C}_{Q} \\
0 & A_{\bar{L}_{\mathrm{p}}} & 0 \\
0 & -\bar{B}_{Q} A_{12} & \bar{A}_{Q}
\end{array}\right) x_{e 2} \\
+\left(\begin{array}{c}
B \\
-B_{2} \\
0
\end{array}\right) \xi+\left(\begin{array}{c}
B G \\
0 \\
0
\end{array}\right) r
\end{array}
$$

$$
y=\left(\begin{array}{lll}
C & 0 & 0
\end{array}\right) x_{e 2}
$$

となる. ここで $x_{e 2}=\left(\begin{array}{lll}x & e_{2} & \bar{\eta}\end{array}\right)^{T}, A_{F_{\varepsilon}}=A+B F_{\varepsilon}$ と おいた。

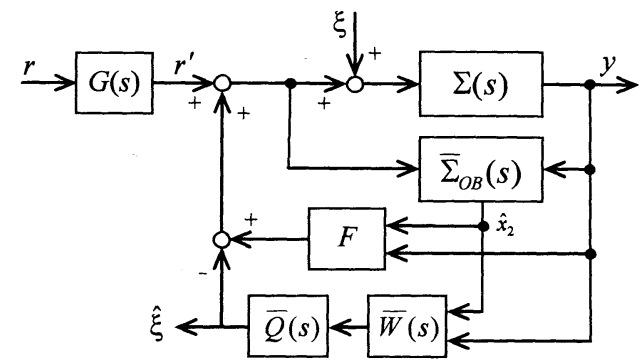

Fig. 4 Reduced order observer-based stabilizing controller

この制御系の外乱推定と外乱除去について, 次 の性質を得る。

[性質 1] (10) $(A, B, C)$ は最小位相系とする.

$\bar{Q}(s)$ の出力を $\hat{\xi} と し \tau \rightarrow 0$ とすると, $\hat{\xi}$ は入力端 に加わる未知外乱 $\xi$ 推定值である.

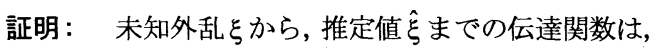

$$
\begin{aligned}
& H_{\hat{\xi} \xi}(s)=\left(\begin{array}{llc}
0 & -\bar{D}_{Q} A_{12} & \bar{C}_{Q}
\end{array}\right) \\
& \cdot\left(\begin{array}{ccc}
s I-A_{F_{\varepsilon}} & -B\left(F_{\varepsilon 2}+\bar{D}_{Q} A_{12}\right) & B \bar{C}_{Q} \\
0 & s I-A_{\bar{L}_{\mathrm{p}}} & 0 \\
0 & \bar{B}_{Q} A_{12} & s I-\bar{A}_{Q}
\end{array}\right)^{-1}\left(\begin{array}{c}
B \\
-B_{2} \\
0
\end{array}\right)
\end{aligned}
$$

であり，整理すると次のようなる．

$$
\begin{aligned}
H_{\hat{\xi} \xi}(s)=\left\{\bar{D}_{Q}+\bar{C}_{Q}\left(s I-\bar{A}_{Q}\right)^{-1} \bar{B}_{Q}\right\} & \\
& \cdot A_{12}\left(s I-A_{\bar{L}_{\mathrm{p}}}\right)^{-1} B_{2}
\end{aligned}
$$

したがって，

$$
\lim _{\tau \rightarrow 0} H_{\hat{\xi} \xi}(s)=I
$$

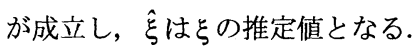

次に，外乱除去に関して次の性質を得る.

[性質 2] $(A, B, C)$ は最小位相系とする. 外乱が 入力端に加わるとき，いかなる未知外乱に対して もフィードバックゲインとオブザーバゲインの極 限特性と, 外乱推定值と外乱の相殺により, 外乱 が出力に与える影響を減少させることができる.

証明: 外乱 $\xi$ か出力 $y$ までの伝達関数は,

$$
\begin{aligned}
& H_{y \xi^{\xi}}(s)=\left(\begin{array}{lll}
C & 0 & 0
\end{array}\right) \\
& \left(\begin{array}{ccc}
s I-A_{F_{\varepsilon}} & -B\left(F_{\varepsilon 2}+\bar{D}_{Q} A_{12}\right) & B \bar{C}_{Q} \\
0 & s I-A_{\bar{L}_{\mathrm{p}}} & 0 \\
0 & \bar{B}_{Q} A_{12} & s I-\bar{A}_{Q}
\end{array}\right)^{-1}\left(\begin{array}{c}
B \\
-B_{2} \\
0
\end{array}\right)
\end{aligned}
$$

であり，整理すると次のようになる。

$$
\begin{aligned}
& H_{y \xi}(s)=C\left(s I-A_{F \varepsilon}\right)^{-1} B \\
& \quad \cdot\left[I-\left\{\bar{D}_{Q}+\bar{C}_{Q}\left(s I-\bar{A}_{Q}\right)^{-1} \bar{B}_{Q}\right\} A_{12}\left(s I-A_{\bar{L}_{\rho}}\right)^{-1} B_{2}\right] \\
& \quad-C\left(s I-A_{F_{\varepsilon}}\right)^{-1} B F_{\varepsilon 2}\left(s I-A_{\bar{L} \rho}\right)^{-1} B_{2}
\end{aligned}
$$

ここで, 補題 1 より $\varepsilon \rightarrow 0$ で $C\left(s I-A_{F_{\varepsilon}}\right)^{-1} B \rightarrow 0$ と なり $H_{y \xi} \rightarrow 0$ となる. さらに, 第 1 項は有限の周

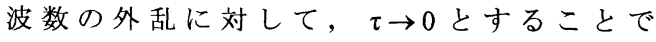
$\left[I-\operatorname{diag}\left((\tau s+1)^{-d_{1}}, \cdots,(\tau s+1)^{-d_{m}}\right)\right]$ も零に近づく.こ れは, 提案手法が $\varepsilon \rightarrow 0, \tau \rightarrow 0$ 二つのパラメー 夕操作で零に漸近するという内部モデル制御と同 じ特性である，第 2 項は，オブザーバの誤差でこ れも $\rho \rightarrow 0$ とすることで, 補題 4 より式(28)が成立 するので, $\varepsilon \rightarrow 0, \rho \rightarrow 0$ により, この項も両方 の極限で各々零に漸近し, これより

$$
\lim _{\varepsilon, \rho, \tau \rightarrow 0} H_{y \xi}(s) \rightarrow 0
$$

が成立する。

さらに, 目標值 $r$ から出力 $y$ までの伝達関数を 考えると，

$$
H_{y r}(s)=C\left(s I-A_{F_{\varepsilon}}\right)^{-1} B G
$$

であるから， $G$ を式(38)と選んでいるため,

$$
\lim _{s \rightarrow 0} H_{y r}(s) \rightarrow I
$$

となり，内部モデル制御の構成と同じになり目標 追従が可能となる.

状態フィードバックとオブザーバを使った安定化 制御則から導く安定化補償器の一般形(1)についてはよ 
く知られているが，ここで示したように設計パラメー 夕を特別な形として選定すると, 補題 3 の内部モデル 制御と同様の外乱推定機能と共にこれを活用した外 乱除去特性が得られる.

\section{3 パラメータの不確かさが存在する場合の特性}

ロボットハンドの粘性抵抗の同定には, 不確かさが 存在しやすい. そこで, パラメータの不確かさがある 場合の制御系の特性について議論しておく.この粘性 抵抗の不確かさは, $(A+\Delta A)$ で $\Delta A=B \delta$ と表記できる. このとき式(4)は,

$$
\dot{x}=(A+\Delta A) x+B u+B \xi, \quad y=C x
$$

となる. そこで，式(40)は次のように整理できる.

$$
\begin{array}{r}
\dot{x}_{e 2}=\left(\begin{array}{ccc}
A_{F_{\varepsilon}}+\Delta A & B\left(F_{\mathrm{\varepsilon} 2}+\bar{D}_{Q} A_{12}\right) & -B \bar{C}_{Q} \\
-\Delta A_{2} & A_{L_{\mathrm{p}}} & 0 \\
0 & -\bar{B}_{Q} C & \bar{A}_{Q}
\end{array}\right) x_{e 2} \\
+\left(\begin{array}{c}
B \\
-B_{2} \\
0
\end{array}\right) \xi+\left(\begin{array}{c}
B G \\
0 \\
0
\end{array}\right) r
\end{array}
$$

$y=\left(\begin{array}{lll}C & 0 & 0\end{array}\right) x_{e 2}$

ここで, $\Delta A_{2}=\left(\begin{array}{ll}\Delta A_{21} & \Delta A_{22}\end{array}\right)$ とおいた.

このとき, 内部モデル制御と同様の手順(9)で次の性 質が示せる.

[性質 3] システム $(A, B, C)$ は $C B=0,|C A B| \neq 0$ を満足し不変零点がないと仮定する.この対象に対し て $\triangle A=B \delta$ なるパラメータ変動が存在する場合, 極限 フィードバックゲイン $F_{\varepsilon}$ で, $\varepsilon$ の調整により閉ループ 系の安定性は保証される。また，

$$
\lim _{\varepsilon \rightarrow 0}\left(s I-A_{F_{\varepsilon}}\right)^{-1} B \rightarrow 0
$$

も成立するので, 外乱推定値 $\hat{\xi} も \xi に$ 近づく.

さらに, 外乱除去特性について次の性質が得られる. [性筫 4] 最小位相系 $(A+\Delta A, B, C)$ に対寸る安定 化補償器の一般形において, $\Delta A=B \delta$ と記述できる場 合, 制御系の設計パラメータを $F=F_{\varepsilon}, \bar{L}=\bar{L}_{\rho}$ お び $\bar{Q}(s), \bar{W}(s)$ を式(36), (37) と選定する.このとき, 各々のパラメータ $\tau, \rho, \varepsilon \rightarrow 0$ とすることで, 外乱から 出力までの伝達関数は零に漸近する.

証明 : 外乱から出力までの伝達関数 $H_{y 5}(s)$ は, 式 (50)から $\Delta A=B \delta, \Delta A_{2}=B_{2} \delta$ および

$$
\begin{aligned}
& \bar{D}_{Q}+\bar{C}_{Q}\left(s I-\bar{A}_{Q}\right)^{-1} \bar{B}_{Q}=\left\{A_{12}\left(s I-A_{\bar{L}_{\mathrm{p}}}\right)^{-1} B_{2}\right\}^{-1} \text { より, } \\
& H_{y \xi}(s) \\
&=\left[C \left[\left(s I-A_{F_{\varepsilon}}\right)-B \delta+B F_{\varepsilon 2}\left(s I-A_{\bar{L}_{\mathrm{p}}}\right)^{-1} B_{2} \delta\right.\right. \\
&\left.\left.\quad+B \cdot \operatorname{diag}\left((\tau s+1)^{-d_{1}}, \cdots,(\tau s+1)^{-d_{m}}\right) \cdot \delta\right]^{-1} B\right] \\
& \\
&+\left[I-\operatorname{diag}\left((\tau s+1)^{-d_{1}}, \cdots,(\tau s+1)^{-d_{m}}\right)\right]
\end{aligned}
$$

となる.よって, 式(53)を得る.

$$
\lim _{\varepsilon, \rho, \tau \rightarrow 0} H_{y \xi}(s) \rightarrow 0
$$

\section{5. 把持のための制御系}

2 章で示した把持システムを具体化するために，4 章で導出した制御系を発展させた把持制御の構成を 図 5 のように提案する. 実際に実験装置として構成し た 1 リンクロボットハンドをもとに把持の流れと制御 の流れを説明する.

図 5 の $\sum(s)$ が制御対象の 1 リンクのロボットハン ドで，その形状は図 8 のようなものである. 簡単のた めに 1 リンクで構成しており，物体を把持できるよう 物体との接触面は可動とし, 接触面が物体にほぼ垂直 にあたるような構造としてある. なお， 1 リンクでは 物体の大きさによって接触面と垂直に接することが 困難となるため, 物体の大きさが不揃いの場合は 20 のリンクの間隔を制御する必要があるが，ここではこ の機能については考えない.

図 5 の制御系の目標值はアームの角度で, 対象物を 十分掴むことのできる角度を与えている. $\Sigma(s)$ への入 力はトルク, $\Sigma(s)$ からの出力はアームの角度で図 1 に示すエンコーダで検出している. $\bar{\Sigma}_{O B}(s)$ は, ロボッ トハンドの数式モデルから得られる式(29), (30)の未 知入力系の低次元オブザーバで, $\Sigma(s)$ への入值(ト ルク) と出力值 (角度)から内部状態である角速度を推 定している. $\bar{W}(s)$ と $\bar{Q}(s)$ で, オブザーバの誤差方程 式の近似逆システム式(35)を構成し，オブザーバで推 定した内部状態 (角速度) と出力值 (角度) から $\Sigma(s)$ の

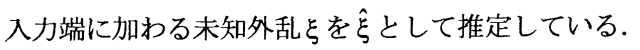

そについては，ロボットハンドにトルクを与えれば 目標の角度に向けて動くが, ロボットハンドが物体に 接触するとハンドの動きに応じた反力により逆のト

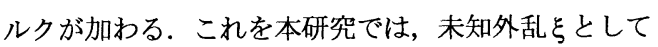
扱う。これらの信号の説明を図 6 に示す.

図 5 の制御系では 2 章で概説したように, CCD カ メラによる物体認識と, 特定した物体に応じた設定把 持力 $\alpha$ をデータベースから読み出す. 物体に接する前 および接触しても反力が小さい, すなわち きの信号の流れは低次元オブザーバを利用した一般 化安定化補償器のそのものであるから図 4 と同じ構成 で図 6 となる.ここで $\xi \geq \alpha$ の判定には, 推定値歺を用いて実行している.八 ンドのモデル，オブザーバおよび近似逆システムは, 次章でまとめて記述する. 
図6の構成であると対象物を十分垷むことのできる 目標角度を与え続ければ， 4 章で得た性質 1,2 により ロボットハンドは目標回転角に追従するため, 軟らか い物体では反力を打消し対象物を押し潰してしまう。 ここで押し潰さないために物体に見合った設定把持 力 $\alpha$ と $\hat{\xi}$ の比較で $\hat{\xi} \geq \alpha$ となった段階で図 5 のスイッ チを切り換えて図 7 に示す信号の流れとする. スイッ チが切り換えられた状態ではハンドを駆動する必要 はなく，対象物の反力と釣り合う力(設定把持力 $\alpha$ )の トルクを加え続けることで把持が可能となる. スイッ チの切り換えには, 切り換え判断と切り換え動作のた め数サンプル分だけ遅れが生じる. この遅れについて の影響および対策等については次章の実験結果で説 明する。

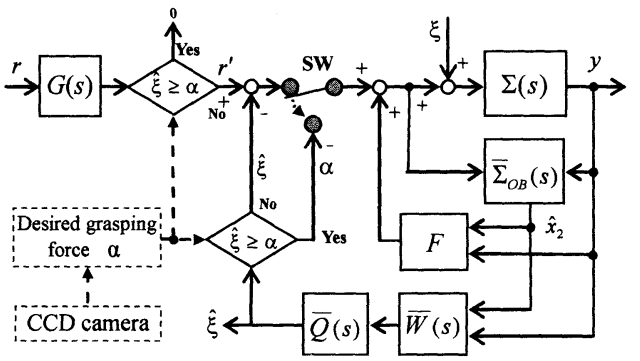

Fig. 5 Proposed control structure

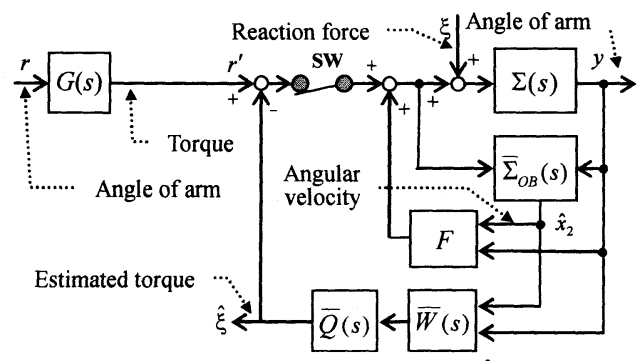

Fig. 6 Proposed control structure $\hat{\xi}<\alpha$

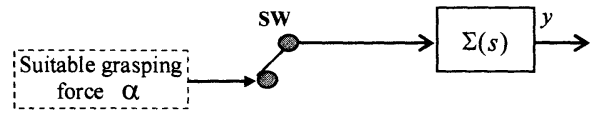

Fig. 7 Proposed control structure $\hat{\xi} \geq \alpha$

\section{6. 実瞒による結果と評価}

6・1 制御系設計 ロボットハンドを簡単化した モデルを図8(a)に，トマトを把持した様子を(b)に示す． また，物理パラメータを表 2 に示す。

Table.2 Physical parameters

\begin{tabular}{|c|c|c|c|c|}
\hline$J$ & \multicolumn{3}{|c|}{ Moment of inartia $\left[\mathrm{kgm}^{2}\right]$} & 0.17 \\
\hline$C$ & \multicolumn{3}{|c|}{ Damping coefficient $[\mathrm{Ns} / \mathrm{m}]$} & 8.1 \\
\hline$T$ & Torque $[\mathrm{Nm}]$ & $\theta$ & Angle & [rad] \\
\hline
\end{tabular}

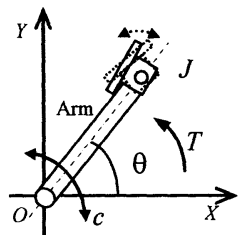

(a)

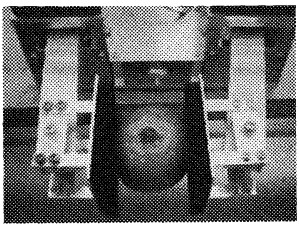

(b)
Fig.8 A model of robot hand

図 8 より，O点周りのハンドの運動方程式は, $\ddot{\theta}+c \dot{\theta}=T$

であるから,ここで状態変数を $x=(\theta \quad \dot{\theta})^{T}$, 操作入力 を $u=T$ として状態変数表現すると, 制御対象は,

$$
\dot{x}=\left(\begin{array}{cc}
0 & 1 \\
0 & -\frac{c}{J}
\end{array}\right) x+\left(\begin{array}{l}
0 \\
\frac{1}{J}
\end{array}\right) T, \quad y=\left(\begin{array}{ll}
1 & 0
\end{array}\right) x
$$

と表すことができる．これに対する低次元オブザーバ は, 式(29)，(30)より,

$$
\left\{\begin{array}{l}
\dot{z}=\left(-\frac{c}{J}+\bar{L}_{\rho}\right) z-\left(-\frac{c}{J}+\bar{L}_{\rho}\right) \bar{L}_{\rho} y+\frac{1}{J} T \\
\hat{x}_{2}=z-\bar{L}_{\rho} y
\end{array}\right.
$$

であり，オブザーバの誤差方程式の近似逆システムは,

$$
\left\{\begin{array}{l}
\dot{\hat{\eta}}=-\frac{1}{\tau} \hat{\eta}+\mu \\
\hat{\xi}=\left(\frac{J}{\tau^{2}}-\frac{c-J \bar{L}_{\rho}}{\tau}\right) \hat{\eta}-\frac{J}{\tau} \mu
\end{array}\right.
$$

と構成でき，ロボットハンドの制御系設計が完了する. 設計パラメータは，シミュレーションと実験による 試行により $\varepsilon=0.018, \rho=0.03, \tau=0.05$ と選定し, こ れらから得られるゲインは, $F_{\varepsilon}=\left(\begin{array}{lll}-54.64 & -1.05\end{array}\right)$, $\bar{L}_{\mathrm{\rho}}=-159.59$ である. なお, サンプリングタイムは $20 \mathrm{~ms}$ とした.

6-2 実硂詰果とその評俩 実験は, CCD カメ ラにより対象物の色と外形の情報から物体の認識を 行う画像認識から，物体把持までの一連の動作を行っ た. 金属立方体とトマトの設定把持力 $\alpha$ は，表 1 のと おり各々 $3.0 \mathrm{Nm}, 1.0 \mathrm{Nm}$ である. 図 9 に金属立方体, 図 10 にトマトを認識し，ハンドに目標入力を与え把 持するまでの実験結果を示す，各々の図の上部が右側 アーム, 下部が左側アームであり, 図中には左右のア 一ムの目標角度と出力角度, 制御入力であるトルクと 外乱推定值である反力をトルクで示している．なお， 横軸は時間である.

物体を認識しハンドに目標角度が与えられてから 約 $4.5 \mathrm{~s}$ までは, アームが物体に触れておらず反力もほ ほ零を示している. $4.5 \mathrm{~s}$ 付近でアームが物体に接触す ると目標值である角度に追従するように入力である 
トルクが増加し，これに伴い反力も増加していること が確認できる. 図 9 の場合，画像から金属立方体を認 識し設定值 $\alpha=3.0 \mathrm{Nm}$ が設定され，反力が $3.0 \mathrm{Nm}$ と なった時点で制御方式が切り換わり設定把持力 $3.0 \mathrm{Nm}$ で把持していることが確認できる. また図 10 も同様にトマトと認識し設定值 $\alpha=1.0 \mathrm{Nm}$ で制御方 式が切り換わり，以後は設定值 $1.0 \mathrm{Nm}$ で適切に把持 していることが確認できる.

ここで図 9, 図 10 に示す左右のハンドの制御トルク は, 物体に接触後から推定トルク分反力である逆トル ク)だけ増大している. 硬い立方体の場合, 制御トルク を増大してもアームは動かないため制御トルクが急 増しているが，図中の出力角度は推定トルクが上昇時 から動いていない, 一方, 図 10 のトマトの場合, 硬 い立方体と比較すると推定トルクの上昇に対してこ の外乱を打ち消し, 出力角度は目標角度に追従してい る様子が認められ性質 2 を実証する結果となっている.

制御トルクは, 推定值 $\hat{\xi} か ゙$ 設定把持力 $\alpha$ を超えた時 点で切り換えるため, 瞬間的に $\alpha$ を超えることになる. 図 9, 図 10 のいずれも瞬間的に制御トルクが上昇しい ているが，時間が短いためトマ、トを潰す力を生じるに は至っていない.これを抑えるためには軟らかい物体 には目標角度をゆっくり与えることで避けられると 考える.

これらの実験より，対象物に見合った力で把持する ロボットハンドについて, 提案する制御システムが有 効であり実現可能であることを示している.

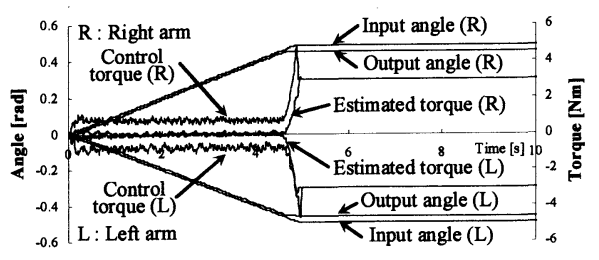

Fig. 9 Experimental result (metallic cube)

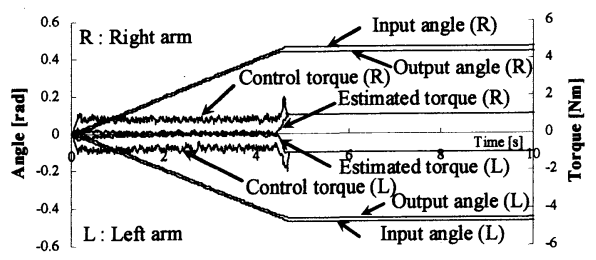

Fig. 10 Experimental result (tomato)

\section{7.おわりに}

本研究では, 視覚情報から物体を認識し, その物体 に見合った力で把持するシステムを提案し, その有効 性を実験により検証した. 圧力センサ等を用いること なく，これを達成するために低次元未知入力オブザー バを利用した一般化安定化補償器の構成で, 内部モデ ル制御と同じ外乱推定と外乱除去特性を持つことを 示し, さらにこれを拡張し把持に適した新しい制御系 を提案し，実験により有効であることを示した.

提案したシステムが今後実用的に意味あるものと するためには，より多くの対象物を把持できるように， 視覚認識システムの改善とデータベースの構築が必 要となる.

最後に有益なご意見をいただきました査読者の方 に心より感謝いたします.

\section{文献}

(1) Zhou,K., Robust and Optimal Control, Prentice Hall (1997)

(2) Morari,M., Zafiriou,E., Robust process control, Prentice Hall (1999).

(3) Image Processing with HALCON (in Japanese), $\operatorname{Lin} X$ Corporation

(4) Kobayashi,N et al., The Limiting Form of Optimal Regulations and Disturbance Decoupling Problem, Transactions of the Society of Instrument and Control Engineers, Vol.34,No.6 (1998), pp.563-570

(5) Suzuki,R et al., Decoupling Control with Limiting Form of Linear Optimal Regulations for Non-minimum Phase System, Transactions of the Institute of Electrical Engineers of Japan, Series C, Vol.119,No.2 (1999), pp.183-189

(6) Kimura,H., Perfect and Subperfect Regulation in Linear Multivariable Control Systems, Automatica, Vol.18,No.2 (1982), pp.125-145

(7) Kimura,H., Sugiyama, O., Design of Robust Controller Using Perfect Regulation and Perfect Observation, Transactions of the Society of Instrument and Control Engineers, Vol.18,No.10 (1982), pp.995-960

(8) Suzuki, $\mathrm{R}$ et al., Multiplicative Effect by Combining IMC Design with Limiting Properties of LQR and Its Application to Trajectory Tracking Control, Transactions of the Japan Society of Mechanical Engineers,SeriesC,Vol.67,NO.663,(2001), pp.3519-3524

(9) Kobayashi,N et al., Disturbance Estimation via IMC Design with Limiting Properties of LQR and Its Application, Transactions of the Japan Society of Mechanical Engineers, Series C, Vol.70,No.695,(2004), pp.1984-1991

(10) Tani,M et al., Generalized Internal Model Control with Servo Compensation using a Reduced Order Observer, Transactions of the Society of Instrument and Control Engineers, Vol.42,No.9 (2006), pp.1027-1034 